\title{
Strategies and Factor Analysis for Current Student High-tech Start-up Ventures in Chinese Colleges
}

\author{
( SUBMITTED BUT NOT PRESENTED)
}

\author{
GONG Qiuping \\ Economics and Management Experimental Teaching Demonstration Center \\ Chongqing Technology and Business University (CTBU) \\ Chongqing 400067, China \\ Email:611354476@qq.com
}

\begin{abstract}
The worldwide governments, particularly current one in China, always encourage their undergraduate to establish student start-up ventures in local incubators around the universities. In the most cases, the student start-ups lack core technology, while only a minimal proportion of start-ups are based on high technology inventions or services. In this paper, the category of student high-tech start-ups were studied in the light of a preliminary survey. The activities of undergraduate entrepreneurs were also investigated by using the general SWOT analysis method. The key factors for these high-tech start-ups were derived, including decision-making efficiency of the entrepreneurial team, the rationality and efficiency of space-time opportunities in the market, the construction of entrepreneurial team, the legal provisions for relevant high-tech products, the technical innovation and security, and financial guarantee. Based on the modelling analysis, a recommended roadmap for high-tech start-ups were proposed in accordance with current undergraduate entrepreneurs in Chinese colleges.
\end{abstract}

Keywords- undergraduate entrepreneur; SWOT analysis; high-tech start-up; incubation platforms of micro-businesses; tactical management;

\section{INTRODUCTION}

When the success stories of Baidu $^{\odot}$, Alibaba $^{\odot}$ and Tencent $^{\Theta}$ (BAT) spread around the world and inspire the entrepreneurial enthusiasm within millions of college students, the Chinese government announced a series of policies to encourage student start-up ventures under the "new normal" economic environment [1, 2]. Traditional labor-intensive enterprises in China have gradually faded and declined because of the demographic dividend and ageing effects [3]. Consequently, the unemployment rate for not only blue-collars but also college students are increasing. The Government would be more preferable to encouraging undergraduate startup ventures, actually equivalent to self-employed business organizations, therefore the unemployed could be temporarily converted into the complimentary category [4].

In fact, not only the Chinese government encourages the undergraduate entrepreneurs, but also the major developed economies or moderate industrialized countries in the world have the similar policies to encourage their national micro or small and medium enterprises (SMEs), especially for the group of college students or undergraduates [5]. The governments also highly encourage the business transformation of scientific patents and other technological achievements from academic circles, for which the student high-tech start-ups or SMEs might become a spontaneous bridge [5]. For example, the Norwegian government has established a national innovation fund, i.e. Innovation Norway ${ }^{\circledR}$, which specifically provide services to their national high-tech enterprises, including student start-ups. A general fund of up to 600,000 Norwegian Krone (Approx. 77,000 USD) are available to apply for each high-tech start-up during the first five years of the establishment. In additional, a large number of tax reduction policy were settled to support the growth of Norwegian SMEs [6]. The Chinese government also supports student start-ups by offering the abatement of tax, interest-free loans and other preferential policies. In 2014, the Chinese government announced to provide small interest-free business loans towards college students or undergraduates with a period of up to 2 years [7]. In May 2015, the central government of China issued an instructive document, entitled "The State Council Opinions on Deepening the Reform of Higher Education in Innovation and Entrepreneurship" [1]. It is noted that the colleges and universities should establish the reasonable credit systems for innovation and entrepreneurship, as well as credit accumulation and conversion regulations, to explore the converting of student activities, such as innovative experiments, academic publications, patent applications, student start-ups etc. into credit points. Moreover, the government document also encourages college teachers to lead their students in the cultivation of undergraduate entrepreneurship [1]. There is no such a national wide mobilization of entrepreneurship in China during the past fifteen years.

As for the government, to encourage student ventures is a wise win-win policy. The establishment of student start-ups will be beneficial to reduce the unemployment rate and drive the high-quality community to open up market potential, and promote domestic demands. The funds from the Government to encourage students' ventures at the early stage are always much lower than the expenditure of compensatory fiscal policies to deal with the social unrest caused by a high unemployment rate. At the same time, the government can also acquire more glory from the people by supporting the young undergraduates, increasing its popularity rating. Therefore, almost all of major countries in the world adopt similar policies to stimulate SMEs or student start-ups to alleviate social contradictions. In this paper, the category of student high-tech start-ups was studied. 


\section{THE TAXONOMY OF STUDENTS START-UPS}

According to the technicality of undergraduate entrepreneurs, the student start-ups can be broadly divided into two categories, high-tech start-ups and low-tech ones, or called conventional ones.

\section{A. The concept portrait painting for low-tech start-ups}

The low-tech or conventional start-ups enjoy a lower threshold of establishment, and their investment cycles are shorter as well. However, due to the lack of technical barriers in their businesses, the stories of successful entrepreneurs will be easily copied by millions of contemporaries, leading to a fierce competition in the limited markets. The profitability of such kind of start-ups could not go beyond the average rate of profit. For example, the case of catering industry in Chongqing city, China is indeed a distinctive typical case, reflecting the characteristics of conventional start-ups (Fig. 1). Similar restaurants or food providers often gather in a highdensity area, while the beginners of these successful restaurants have to be submerged among the intratype competitors. As long as other investors in China notice a profitable opportunity, the market strategy of any low-tech entrepreneurs will be replicated dramatically. In the absence of monopoly power, the competition will generally make the profit margins of any low-tech business decrease onto the average level. The government might readily accept this situation, since it can digest a large quantity of conventional unemployment. However, for individual undergraduates, the long-term prospects for their low-tech start-ups may be bleak.

\section{B. The features of high-tech start-ups}

The features of high-tech start-ups are different from the conventional ones. Comparing with the previous category, its initial threshold is higher, and the investment cycle will be much longer. Namely, it is difficult to gain the profit immediately. Once the successful factors of the start-ups were proven, the technical barriers may contain most contemporary competitors, so the profit margins of high-tech start-ups could be maintained for a long period. However, due to the risks of the high-tech businesses, few undergraduates are willing to choose this type of business models. A typical case was reported recently in the news media of China [9]. The winner of the student contest of Qi Dian University, Zhengmin Chen has no money to apply for the patent for his invention, a newconcept high-performance motor. In other words, he is not willing to invest into their own high-tech project, even the patent application fee of around CNY 4,000 for his own invention. The prizewinner expected some investors to take the risk for his high-tech project. Anyway, high risks usually imply high profits. As the successful BAT also came from high-tech start-up ventures, the long-term prospects for successful high-tech start-ups are probably immeasurable.

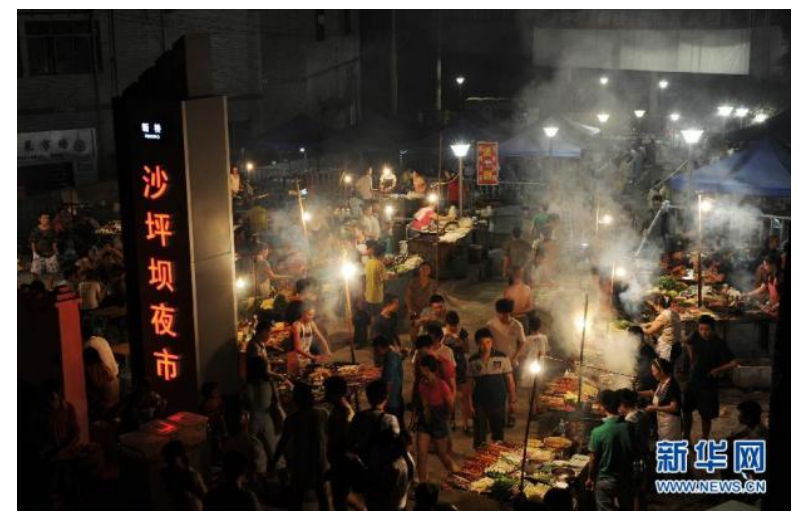

Fig. 1. A typical scene for conventional catering micro-business in Chongqing city.(Figure courtesy of Sohu ${ }^{\odot}$ News [8])

\section{SWOT ANALYSIS ON STUDENTS HGH-TECH START-UPS}

The SWOT analysis for student high-tech start-ups was performed as usual, shown in the Table 1.

\section{A. Strengths}

First, the college campus is often close to the hi-tech research center of academic units, which make the college students more accessible to the scientific frontiers of knowledge and more accessible to the researchers and scholars who own the technology, even some college students directly involved in the research projects prior to their graduation.

Secondly, the exchange of various discipline in a comprehensive university was easy and frequent, owning to the high-density collective life in a general Chinese campus. College students could obtain enough opportunities for their own circle of friends. The friend sphere may include not only the students major at science and engineering, the ones with economics or other knowledge background, which multidisciplinary group will natural give birth to an initial team of a student high-tech start-up. The consortium of a company is always the core of the whole business. Obviously, because of personal friendship, the student start-ups will gather closer than an entrepreneurial team formed only by some common interests. The stabilizing factors of the initial consortium also come from the natural relationship of teacher and students, when the owner of the core high technology for the start-up is just the previous teacher in the college.

At last, the curiosity and adventure preferences of college students make these idealistic individuals pursue long-term goals, so they are willing to tolerate low returns at the beginning stage. They are used to facing brand-new information, allowing them to form associative thinking and obtain optimistic long-term expectations for their high-tech projects. Besides, the college students in the pioneering period are young and have generally good physical conditions. They have no family, no children to take care, so they could dedicate themselves entirely to the start-ups. All these features are in line with the characteristics and development process of a high-tech start-up. 
TABLE I. SWOT ANALYSIS OF STUDENT HIGH-TECH START-UPS

\begin{tabular}{|c|c|c|}
\hline & Strength & Weakness \\
\hline External & $\begin{array}{l}\text {-Easy access to the } \\
\text { core technology; } \\
\text {-Easy to establish a } \\
\text { multi-disciplinary } \\
\text { team; } \\
\text {-Young, health, vivid; }\end{array}$ & $\begin{array}{l}\text {-Lack of experience; } \\
\text {-Lack of } \\
\text { confidence; } \\
\text {-Lack of authority; } \\
\text {-Lack of } \\
\text { independent R\&D } \\
\text { capability; } \\
\text {-high risks, difficult } \\
\text { to obtain financing; }\end{array}$ \\
\hline Opportunities & SO & $W O$ \\
\hline $\begin{array}{l}\text {-opportunities in } \\
\text { "new normal" market } \\
\text { environment; } \\
\text {-The exciting } \\
\text { Chinese stock market } \\
\text { indirectly ease the } \\
\text { financing difficulties; } \\
\text {-A large amount of } \\
\text { precipitated } \\
\text { technology; } \\
\text {-Support in the } \\
\text { campus incubator; }\end{array}$ & $\begin{array}{l}\text {-Take advantage of the } \\
\text { existing interpersonal } \\
\text { relationship and } \\
\text { technology in the } \\
\text { university; } \\
\text {-Build a complete } \\
\text { entrepreneurial team } \\
\text { with fully knowledge } \\
\text { storage; } \\
\text {-Obtain a convenient } \\
\text { financing channel } \\
\text { through the campus } \\
\text { incubator. }\end{array}$ & $\begin{array}{l}\text {-Hire experienced } \\
\text { senior consultants } \\
\text { during the growth } \\
\text { stage; } \\
\text {-Sign a commercial } \\
\text { agreement with the } \\
\text { IPR owners; } \\
\text {-Build prospective } \\
\text { decision-making } \\
\text { and supervising } \\
\text { mechanisms; } \\
\text {-Sign a staircase } \\
\text { financing agreement }\end{array}$ \\
\hline Threats & $S T$ & $W T$ \\
\hline $\begin{array}{l}\text {-Mature competitors } \\
\text { in the market; } \\
\text {-The consumers' } \\
\text { ability to accept new } \\
\text { products or services; } \\
\text {-The change in the } \\
\text { laws and regulations; } \\
\text {-The intervention of } \\
\text { a strong competitor } \\
\text { outside the current } \\
\text { market; }\end{array}$ & $\begin{array}{l}\text {-Arrange a } \\
\text { professional team } \\
\text { member to constantly } \\
\text { monitor competitors; } \\
\text {-Establish confidential } \\
\text { discipline; } \\
\text {-Evade the IPR } \\
\text { barriers of major } \\
\text { competitors, } \\
\text { - Study the relevant } \\
\text { laws }\end{array}$ & $\begin{array}{l}\text {-ERP simulation to } \\
\text { check the market } \\
\text { strategy } \\
\text {-Preset the "retreat" } \\
\text { conditions and } \\
\text { relevant measures } \\
\text { for the worst cases; } \\
\text {-Preset the "victory" } \\
\text { conditions and the } \\
\text { proper measures; }\end{array}$ \\
\hline
\end{tabular}

\section{B. Weaknesses}

Although college students have various advantages, they also have many drawbacks. They do not have much life experience, let alone entrepreneurial ones. Most of them do not know the real circumstances of the society and have no idea about the current market. Therefore, they often makes false decision at the early stage, leading to aggressive investment in their projects. In addition, they often lack practical experience and perseverance to solve a thorny problem. When the start-ups face temporary setbacks, they may not be able to solve the problems, and eventually give up their long-term plan. From the management point of view, the student entrepreneurial team may be have a democracy natural on the other hand, it means that this team lacks authority, difference opinions might frequently appear, and result in indecisive discussion and bungled opportunities.

For the student high-tech start-ups, in fact, the college students do not have much technology, because they are generally not professional researchers, unless the entrepreneurial team includes the core person like Steve Jobs, Bill Gates, et al. Since common college students in high-tech start-ups often cannot have an independent R\&D capability, they have to rely on an external technical source, for example, a research group in the university. Therefore, the student hightech start-ups often do not have a complete intellectual property right (IPR) of their core technology before they sign a transfer agreement for the technology. Without such an agreement at the beginning stage, some economic disputes might be generated in the payback period. Both the R \& D team and the marketing group always expects high payback for their effort.

In the financial aspect, the student start-ups are often difficult to obtain enough financing supports due to high risks and a low credit level of the start-ups. Besides the financial problems, immature entrepreneurial team often have to face the fatal competition of some mature high-tech companies in the market. The student high-tech companies can seek for the first pot of gold in the selected field that the opponents neglected.

\section{Opportunities}

With the advance of Chinese "new normal" economic policies, the student high-tech start-ups receive a full range of policy support. Under the "new normal" economic environment, traditional industries are being replaced by hightech ones. The chaotic market environment disrupted the market distribution of monopoly interests, emerging some fleeting opportunities for new start-ups.

Since October 2014, the exciting Chinese stock market gave the Chinese high-tech enterprises and their investors some glorious prospects. It is implied that, as long as the development of the high-tech enterprises in line with the expectations of common investors, the stocks of these hightech companies could be sold at a good price in the stock market within a short period, regardless of the long distribution cycle of the real products. This investment environment offers opportunities both for the companies in the GEM board of Chinese stock market and for burgeoning hightech start-ups. Some promising high-tech start-ups can receive the investment of venture capital companies. The exciting stock market indirectly ease the financing difficulties of student high-tech ventures, whereas the conventional start-ups are often impossible to obtain such kind of financing.

Furthermore, in the traditional Chinese university environment, most research achievements are precipitated in the laboratories or libraries, instead of entering the market. The owners of the technology are often busy at teaching and scientific activities. In general, they are glad to see that some student entrepreneurial teams commercialize their research achievements. Owing to the natural relationship of the teacher and students, the student teams can easily obtain the access to the core technology by some specific methods at a low cost, for example, the forming of technology investment. Sometimes, the student start-ups can even get more support for the universities, such as free offices in the campus incubator.

\section{Threats}

The mature high-tech enterprises in the existing market are natural competitors and serious threats for student high-tech start-ups. In terms of market experience, management experience, the technological level, $R \& D$ capabilities, financial strength, staffing quality, all aspects of the student ventures are located at an inferior position. If student start-ups are like shrimps, their mature competitors on the market could 
be similar to sharks or dinosaurs. Obviously, the student hightech start-ups will end in failure if the selected objectives of start-ups are not the market gap of their competitors. In general, only in the market gap that their mature competitors overlooked, the student start-ups could probably find a successful breakthrough.

Another potential threat comes from the consumers' ability to accept new products or services. Since the high-tech entrepreneur's breakthrough lies in some ignored market gaps, the emerging products or services must be some strange things to the consumers. There is a challenge for Chinese consumers to unfamiliar goods or services, so the student high-tech startups would meet a general problem of marketing. The hostile competitors may be perceived during the stage of market promotion, so the potential anti-competition actions from the competitors are probably taken. For example, Japanese companies often reduce the prices of their electromechanical products just after they noticed some Chinese competitors meet with success in the development of competing products, in order to "punish" the emerging competitors. If the new product indeed shows a promising market prospect, the matured competitors generally have the ability to develop similar functional products within six months, which could also bypass the patent protection, such as the relationship between iPhone ${ }^{\circledR}$ and Samsung ${ }^{\circledR}$ smart phones. If the promotion stage of the new products is too long, the student start-ups might lose their market opportunities.

To obtain a chance for development, high-tech start-ups have to collect enough financial support during the careless period of the mature competitors. The start-ups are required to earn the first pot of gold and achieve a certain IPR within the limited period. Therefore, both the factors of financing and development speed have to be considered. In addition, the change in the laws and regulations is also a challenge. Hightech products are likely to encounter conventional regulations obstruct in the introduction period, for instance, new mobilehealth APPs are required to apply for the license for medical equipment, though they are not traditional medical devices. Another example is the APP of "Fast Taxi". When this APP appears in the market, there is no regulatory barriers. However, a new judicial interpretation were launched later due to the protest of taxi drivers.

Finally, potential threats could come from the intervention of a strong competitor outside the current market. Because of the WTO agreement, the protection period of the Chinese market will end in 2015. The domestic start-ups have to face some unknown strong competitors from the external world. Sometimes the market turmoil is an opportunity, but it is often a devastating factor.

\section{StRATEGIC ANALYSIS OF High-TECH START-UPS}

\section{A. Growth strategy of student high-tech start-ups}

According to the results of SWOT analysis, the growthoriented strategy for student high-tech start-ups is to take advantage of the existing interpersonal relationship and technology in the university, and gain the right to use the core technology at the lowest cost. In addition, the student start-ups could build a complete entrepreneurial team with fully knowledge storage, and obtain a convenient financing channel through the campus incubator. Under the current economic environment, it is the best strategy for the student start-ups to take advantage of the technical reserves and the business incubator inside their alma maters.

In order to avoid the weaknesses of students, especially lack of experience, it is best for the student teams to employ experienced senior consultants with common interests during the growth stage of start-ups. These consultants could be parttime, but should be real experts in the relevant fields, for example, a technical advisor for $\mathrm{R} \& \mathrm{D}$, a marketing consultant for marketing, a legal consultant for IPR, et al. In the early stage of start-ups, the consultancy fees sometimes could be paid in the form of granting technology shares of the entrepreneurship rather than in cash. Similarly, to avoid future IPR disputes, the wise strategy is to sign a commercial agreement with the IPR owners of relevant core technologies as earlier as possible. The payment for core technology could also in the form of transferring shares of the start-up company. All these legal documents will clearly identify the distribution framework of future benefits and avoid unnecessary legal actions in the future.

The prospective decision-making and supervising mechanisms in student high-tech start-ups should also be designed and finalized in the early stage, referring to some good examples like BAT. After choosing the most capable person in the start-up team as the leader, the decision-making mechanism should give the leader the ad hoc right to make decision efficiently without prejudice to the interests of the board. Due to the importance of full and timely financing to a high-tech start-up, the entrepreneurial team should solve the problem of financing channels at least prior to the marketing of their new products. To sign a staircase financing agreement could be a solution to provide adequate financial support for the R\&D of the high-tech product and the subsequent marketing process.

\section{B. Defensive strategy of student high-tech start-ups}

Facing the impact of the market, the entrepreneurial team need arrange a professional team member to constantly monitor the market trends of major competitors from the beginning, and develop a raid-type marketing strategy for the first pod of gold. The strategy need be timely adjusted in term of the change of major competitors. Before the new products appear into the market, at least a sand-table simulation of Enterprise Resource Planning (ERP) has to be performed to check the market strategy and ensure the successful promotion of the new products. In order to achieve the effect of surprise attack towards the major competitors, the whole team has to establish confidential discipline to prevent the major competitors from being aware of the latent start-ups beforehand.

The technical specialist in the entrepreneurial team ought to study the IPR and technology of the major competitors. After that, the technical roadmap of the start-up should be made to evade the IPR barriers of major competitors, even avoid their expertise field. On the other hand, a new patent application for the new products of the start-ups should be applied to make IPR barriers for the opponents. A market 
commissioner is also required in the team, responsible for investigating the market and studying of consumers' psychology. Accordingly a relevant marketing program should be developed for selected user groups. In the start-up team, there also need a law commissioner to study the relevant laws and regulations, avoiding conflicts with the laws. The legal protection ought to be designed as far as possible before the new products are launched to the market.

Some feasible counterattack strategies of the major competitors could be found in the ERP experiments. Since the student venture team often lacks a powerful line of psychological defense, they are often defeated by their terrorstricken minds at unexpected counterattacks of the major competitors. Therefore, the defense program should be scheduled before the promotion of new products. The "retreat" conditions and response measures in the worst cases can help the start-ups to evaluate the situation and cover their own retreat. Similarly, the student venture team has to set the "victory" conditions and the proper measures in their marketing plan to consolidate the fruits of victory. The "victory" conditions could prevent some irrational activities of the start-up in the triumphant stage.

\section{General objectives of student high-tech start-ups}

The low-tech start-ups are likely transformed into regional service suppliers or local manufacturers, whereas student high-tech start-ups are often merged by large capital in general It is almost impossible for a high-tech SME to grow up in accordance with the classic path of capital accumulation, because the primitive accumulation takes time, but the present market will not give enough time for a SME to grow. Under the fierce competition, the single technical dominance of a high-tech product often can maintain for a short time. If the SME does not agree to cooperate with large capital, it will be demolished by the fierce competition. Therefore, after the successful declaration of the high-tech start-up, the mergers and acquisitions by large capital is usually the best destination of a high-tech start-up. The success stories of BAT are only the special cases in a special era of Chinese market. In the opening market of the globalization era, such myths are difficult to repeat. With respect to the mighty capital market, the only difference of various successful high-tech start-ups are the selling price and time.

\section{ACKNOWLEDGMENT}

The author would like to express the sincere thanks to the colleagues, Guangming Rao, Li Zhou, Guilin Fan et al., for their generous instruction, encouragement and precious technical discussion. The research activities were also sponsored by the student's association, Mozi's Volunteer Group in Zhixing College of Hubei University, the CTBU students' ERP Club, the CTBU students' Investment Club and the Students' Innovation and Entrepreneur Union in CTBU.

\section{REFERENCES}

[1] http://www.gov.cn/zhengce/content/2015-05/13/content_9740.htm. Accessed on $1^{\text {st }}$ June 2015.

[2] http://www.most.gov.cn/mostinfo/xinxifenlei/fgzc/gfxwj/gfxwj2015/201 504/t20150422_119124.htm. Accessed on $1^{\text {st }}$ June 2015.

[3] S. Liu and X. Yuan, "Chinese aging population: Progress, Problems and Policies," Academic Journal of Zhongzhou, [in Chinese], vol. 6, 2011, pp. 122-126.

[4] X. Chen and B. Li, "The historical changes of Entrepreneurship policies in China," vol. 30(3), 2014, pp. 20-25.

[5] L. Grilli, S. Murtinu, "Government, venture capital and the growth of European high-tech entrepreneurial firms", Research Policy, vol. 43(9), 2014, pp. 1523-1543.

[6] http://www.innovasjonnorge.no/. Accessed on $30^{\text {th }}$ May 2015.

[7] http://bank.hexun.com/2014-07-18/166746687.html. Accessed on $30^{\text {th }}$ May 2015.

[8] http://roll.sohu.com/20110902/n318180976.shtml. Accessed on $29^{\text {th }}$ May 2015.

[9] http://news.ittime.com.cn/news/news_4852.shtml. Accessed on $2^{\text {nd }}$ June 2015 . 